\title{
Values and the Rule of Law: Foundations of the \\ European Union - An Inside Perspective from the ECJ
}

T Von Danwitz*

\section{P.E.R}

Pioneer in peer-reviewed, open access online law publications

Author

Thomas von Danwitz

Affiliation

President of the IVth Chamber of the European Court of Justice

Email

Thomas.Von_Danwitz@curia.euro pa.eu

Date of submission

20 March 2018

Date published

3 April 2018

Editor Prof C Rautenbach

How to cite this oratio

Von Danwitz T "Values and the Rule of Law: Foundations of the European Union - An Inside Perspective from the ECJ" PER / PELJ 2018(21) - DOI

http://dx.doi.org/10.17159/17273781/2018/v21i0a4792

Copyright

http://dx.doi.org/10.17159/1727-

3781/2018/v21i0a4792

\section{Abstract}

Let us remember what has been written, ratified and set into force with the Treaty of Lisbon. The preamble of the Charter of Fundamental Rights starts out by stating: "The peoples of Europe, in creating an ever closer union among them, are resolved to share a peaceful future based on common values." And it goes on: "Conscious of its spiritual and moral heritage, the Union is founded on the indivisible, universal values of human dignity, freedom, equality and solidarity; it is based on the principles of democracy and the rule of law. It places the individual at the heart of its activities, by establishing the citizenship of the Union and by creating an area of freedom, security and justice." Even if a cynic might have considered these words to be merely a lip service unlikely to disturb the power-play European governments were so eagerly engaged in, the Charter nonetheless became the supreme law of the land and the preferred tools of the trade of a rather awkward species of beings, already of bad repute for relying on the mere wording of legal acts, and even worse, for taking rights seriously: judges - in particular those of the European Court of Justice.

\section{Keywords}

Rule of law; European Union; European Court of Justice; Charter of Fundamental Rights. 
Only a few years ago it would have seemed rather inconceivable that a major conference, such as the one which I feel very honored to open with this presentation on values and the rule of law would or could have been introduced in those terms. Not that values or the rule of law were absent from European Union law, but rather because dealing with that subject would have been considered as too academic or at least impractical, too sophisticated and certainly completely out-dated. The values enshrined in the Treaties and in the Charter of Fundamental Rights have been elaborated and put in the most prominent place to be found in Union law, because the esteem in which those values and the rule of law, designed to ensure their respect, are held, seemed to be uncontested and incontestable. Unfortunately, things have changed.

So, let us remember what has been written, ratified and set into force with the Treaty of Lisbon. The preamble of the Charter of Fundamental Rights starts out by stating: "The peoples of Europe, in creating an ever closer union among them, are resolved to share a peaceful future based on common values." And it goes on: "Conscious of its spiritual and moral heritage, the Union is founded on the indivisible, universal values of human dignity, freedom, equality and solidarity; it is based on the principles of democracy and the rule of law. It places the individual at the heart of its activities, by establishing the citizenship of the Union and by creating an area of freedom, security and justice." Even if a cynic might have considered these words to be merely a lip service unlikely to disturb the power-play European governments were so eagerly engaged in, the Charter nonetheless became the supreme law of the land and the preferred tools of the trade of a rather awkward species of beings, already of bad repute for relying on the mere wording of legal acts, and even worse, for taking rights seriously: judges - in particular those of the European Court of Justice.

Prof Dr Dr hc Thomas von Danwitz. President of the IVth Chamber of the European Court of Justice. He is also a member of the editorial board of PER. This presentation 
I.

Would such a cynic tell people today that it was simply wrong to make such promises which imply that all those rights have to be respected, all the more because there are judges empowered to ensure that European institutions and national governments cannot escape from what has been promised to the peoples of Europe? Maybe there are such voices and, in the end, it will doubtlessly be for each nation to shape its own destiny. Not as a judge, but as a European citizen born in 1962 right on the brink of the Cuban missile crisis, let me quite simply express my sentiment in terms of gratitude: Europe owes so much to the United Kingdom, not only for its very existence and to a large extent for the freedom of its societies, but in particular for the respect for values and fundamental rights ensured by the rule of law, inter alia and in particular in the example given by the United Kingdom. For this reason I continue to believe that there was nothing wrong in proclaiming the common values and fundamental rights of the peoples of Europe to be binding rules in the treaties of the European Union. To me, it is rather the respect paid to those values and rights which reflects the essence of what Europe stands for.

That is why, in the current debate on the value of the European Union and the pursuit of European integration, despite all the different manifestations of crisis which have profoundly affected the lives of our fellow citizens and have certainly upset the minds of many, the values of the European Union should not be seen as a cause of that crisis but as an important element tending towards overcoming the tiredness which has spread in Europe and to win back the hearts and minds of Europeans. Voices that confront us with a picture of Europe that looks more like a caricature than the reality of things tend to neglect the paramount importance the acquis of the European Union represents in terms of the rights granted to citizens, the guarantees given

is an adapted version of a keynote delivered at the Centre of European Law Annual European Law Conference held at King's College (London) on 2 March 2018. 
to strengthen the rule of law, and the policies enacted to protect the common values on which the Union is founded.

In this context it appears particularly important to recall first of all the foundations of the European Union, which consists of a community based on the rule of law. It is worth quoting the words used by the first President of the European Commission, Walter Hallstein, to characterize this community, during his famous speech delivered nearly 56 years ago, on $12^{\text {th }}$ of March 1962, at the University of Padua. In his words,

\begin{abstract}
This community is not due to military power or political pressure, but owes its existence to a creative act. It is based on sound legal standards and its institutions are subject to legal control. For the first time, the rule of law takes the place of power and its manipulation, of the equilibrium of forces, of hegemonic aspirations, and of the game of alliances. [...] In the relations between Member States, violence and political pressure will be replaced by the preeminence of the law.
\end{abstract}

The way in which Hallstein continues to characterize the European Community to this day is still a most striking expression of the very nature of the European Union. Let me quote again:

With its non-terminable founding treaty, the Community has a kind of
constitution in which the formation, composition, functions, competences and
interactions between the Community institutions and their relations with the
citizens of the Member States and the Community are regulated.

To put it simply, the treaties completed since 2009 by the Charter of Fundamental Rights form an integral part of the social contract by which our states are committed to the citizens.

If one takes into account the recent evolutions in other parts of the world and the dangers which persist even inside the European Union, especially as regards the fight against corruption or for civil liberties, would it appear to be conceivable that Europe might turn away from its profound attachment to the rule of law and its common values? Could one reasonably be in disagreement with those common values? From a historical perspective it seems to me that the achievement of the European project and the pursuit of integration simply do not make any sense without a profound attachment 
to the common values of the European Union and, in particular, to the rule of law with the checks and balances which it provides. Indeed, those common values guarantee in a very essential manner the smooth functioning of the Union's institutions and of the Member States implementing Union law.

II.

At the Court of Justice of the European Union judges are, by the very nature of the tasks entrusted to them, sufficiently well placed to say a word about such matters, because we are seized daily, in one way or another, by actions brought against allegedly unlawful acts of Union institutions or national authorities implementing EU law. The task of the Court of Justice is, on the one hand - you all know this - to ensure that the Union institutions act lawfully when they exercise their important powers. This task is complemented by a true scrutiny of the "constitutionality" of EU legislation, even when enacted by democratically legitimized institutions such as the European Parliament and the Council, a control that is exercised against the benchmark of the Treaty provisions, the general principles resulting from common constitutional traditions of the Member States and, in particular, fundamental rights. It is precisely this last mission, to guarantee the protection of fundamental rights, which was crowned by the entry into force of the Charter of Fundamental Rights with the Lisbon Treaty. On the other hand, the Court of Justice also has the task of ensuring the Member States' compliance with their EU obligations, in particular by means of actions for failure to fulfil obligations brought by the European Commission.

1.

However, the vigilance of individuals in respect of the rights conferred on them by the Union has proved over the years to be a particularly important tool for ensuring the proper application of Union law within the Member States. The instrument of the preliminary ruling procedure hence enables or 
even requires any national court to apply to the Court of Justice in case of doubt about the interpretation or the validity of an act of the Union. This makes it possible to attain a uniform interpretation of EU law, valid in all the Member States, and thus to contribute to the consistency of EU law. Thanks to this instrument, the citizens of the Union play a major role in the smooth functioning of the European Union. It confirms that the citizens are indeed at the heart of all Union action. Its tasks require the Court of Justice regularly, and sometimes in very delicate circumstances, to adjudicate on the common values and on the raison d'être of the Union, as well as on the added value that EU law brings to the daily life of citizens of the Union, aspects which are quite often intimately intertwined in one single case.

It is commonplace that the Court of Justice has, over the years of its case law, consistently ensured the recognition and application of expressions of the rule of law such as the principles of legality ${ }^{1}$ and legal certainty, ${ }^{2}$ the protection of legitimate expectations, ${ }^{3}$ the principle of proportionality, ${ }^{4}$ the

1 Judgment of 12 July 1957, Algera et al. $v$ Common Assembly, $7 / 56$ and 3/57 to 7/57, EU:C:1957:7; Judgment of 22 March 1961, Snupat v High Authority, 42/59 and 49/59, EU:C:1961:5; Judgment of 17 April 1997, de Compte v Parliament, C-90/95 P, EU:C:1997:198, paragraph 35; Judgment of 24 January 2002, Conserve Italia v Commission, C-500/99 P, EU:C:2002:45; paragraph 90; also see the Judgment of 7 January 2004, X, C-60/02, EU:C:2004:10, paragraph 63; Judgment of 3 May 2007, Advocaten voor de Wereld, C-303/05, EU:C:2007:261, paragraphs 49-50.

2 Judgment of 9 July 1981, Gondrand and Garancini, 169/80, EU:C:1981:171, paragraph 15; Judgment of 13 February 1996, Van Es Douane Agenten, C-143/93, EU:C:1996:45, paragraph 27; Judgment of 14 April 2005, Belgium v Commission, C-110/03, EU:C:2005:223, paragraph 30; Judgment of 14 September 2010, Akzo Nobel Chemicals and Akcros Chemicals v Commission, C-550/07 P, EU:C:2010:512, paragraph 100.

3 Judgment of 12 July 1957, Algera et al. v Common Assembly, 7/56 and 3/57 to 7/57, EU:C:1957:7; Judgment of 22 March 1961, Snupat v High Authority, 42/59 and 49/59, EU:C:1961:5; Judgment of 13 July 1965, Lemmerz-Werke v High Authority, 111/63, EU:C:1965:76; Judgment of 25 February 1969, Klomp, 23/68, EU:C:1969:6, paragraph 44; Judgment of 11 July 2002, Marks \& Spencer, C-62/00, EU:C:2002:435, paragraphs 44-45; Judgment of 18 June 2013, Schenker \& Co. et al., C-681/11, EU:C:2013:404, paragraph 41; Judgment of 12 December 2013, Test Claimants in the Franked Investment Income Group Litigation, C-362/12, EU:C:2013:834 , paragraphs 44-45.

4 Judgment of 17 December 1970, Internationale Handelsgesellschaft, 11/70, EU:C:1970:114, paragraph 12; Judgment of 29 April 1982, Merkur Fleisch-Import, 147/81, EU:C:1982:131, paragraph 12; Judgment of 17 May 1984, Denkavit Nederland, 15/83, EU:C:1984:183, paragraph 25; Judgment of 11 July 1989, Schräder HS Kraftfutter, 265/87, EU:C:1989:303, paragraph 2; Judgment of 8 July 
safeguarding of the rights of defence, ${ }^{5}$ the right to be heard ${ }^{6}$ and the right of access to the file, ${ }^{7}$ as well as the obligation to state reasons. ${ }^{8}$ Consequently, in its groundbreaking judgement Les Verts $v$ Parliament, ${ }^{9}$ the Court has officially accredited the concept of the European Union as being a community of law. Ever since, the Court has consistently abided by this concept, especially in cases in which there was a need to safeguard effective legal protection for Union citizens. Let me just cite the land-mark decisions in Johnston and Heylens, which in today's world are restated in different fields of law such as in Chalkor, in Schrems or in Berlioz Investment

2010, Afton Chemical, C-343/09, EU:C:2010:419, paragraph 45; Judgment of 23 October 2012, Nelson et al., C-581/10 and C-629/10, EU:C:2012:657, paragraph 71; Judgment of 22 January 2013, Sky Österreich, C-283/11, EU:C:2013:28, paragraph 50.

5 Judgment of 4 July 1963, Alvis v Council, 32/62, EU:C:1963:15; Judgment of 24 October 1996, Commission v Lisrestal et al., C-32/95 P, EU:C:1996:402, paragraph 21; Judgment of 21 September 2000, Mediocurso v Commission, C-462/98 P, EU:C:2000:480, paragraph 36; Judgment of 18 December 2008, Sopropé, C-349/07, EU:C:2008:746, paragraph 36-37; Judgment of 21 December 2011, France vs. People's Mojahedin Organization of Iran, C-27/09 P, EU:C:2011:853, paragraph 6566; Judgment of 10 September 2013, G. and R., C-383/13 PPU, EU:C:2013:533, paragraph 32.

6 Judgment of 18 May 1982, AM \& S Europe v Commission, 155/79, EU:C:1982:157, paragraph 18; Judgment of 18 October 1989, Orkem v Commission, 374/87, EU:C:1989:387, paragraph 32; Judgment of 14 September 2010, Akzo Nobel Chemicals and Akcros Chemicals v Commission, C-550/07 P, EU:C:2010:512, paragraph 92.

7 Judgment of 13 February 1979, Hoffmann-La Roche v Commission, 85/76, EU:C:1979:36, paragraph 9; Judgment of 8 July 1999, Hercules Chemicals v Commission, C-51/92 P, EU:C:1999:357 n paragraph 75; Judgment of 15 October 2002, Limburgse Vinyl Maatschappij et al. v Commission, C-238/99 P, C-244/99 P, C-245/99 P, C-247/99 P, C-250/99 P to C-252/99 P and C-254/99 P, EU:C:2002:582 paragraph 315; Judgment of 7 January 2004, Aalborg Portland et al. v Commission, C-204/00 P, C-205/00 P, C-211/00 P, C-213/00 P, C-217/00 P and C-219/00 P, EU:C:2004:6, paragraph 68; Judgment of 1 July 2010, Knauf Gips v Commission, C-407/08 P, EU:C:2010:389, paragraph 22.

8 Judgment of 22 June 2004, Portugal v Commission, C-42/01, EU:C:2004:379, paragraph 66; Judgment of 15 December 2005, UniCredito Italiano, C-148/04, EU:C:2005:774, paragraph 99; Judgment of 7 September 2006, Spain v Council, C-310/04, EU:C:2006:521, paragraph 57; Judgment of 6 March 2003, Interporc v Commission, C-41/00 P, EU:C:2003:125, paragraph 55; Judgment of 29 September 2011, Elf Aquitaine $\vee$ Commission, C-521/09 P, EU:C:2011:620, paragraph 14; Judgment of 7 March 2013, Switzerland v Commission, C-547/10 P, EU:C:2013:139, paragraph 67. Judgment of 23 April 1986, Les Verts v Parliament, 294/83, EU:C:1986:166. 
Fund. ${ }^{10}$ In particular since the Charter of Fundamental Rights entered into force, the Court of Justice has shown in its case-law that it takes rights seriously and is committed to the key promise of the Charter, stating that "it is necessary to strengthen the protection of fundamental rights in the light of changes in society, social progress and scientific and technological developments."

2.

But let us go beyond those commonplaces. In recent years, the respect for the rule of law has not always been a priority on the agenda of European institutions and Member States. In that respect the Kadi-jurisprudence is quite paradigmatic not only because it illustrates perfectly what the promise, reaffirmed in article 47 of the Charter of Fundamental Rights, of a right to an effective remedy before a tribunal truly implies, but more so because the institutions of the European Union and the Member States appearing before the Court of Justice advocated in perfect harmony that there was no need for a judicial scrutiny of those blacklisting decisions. Despite the delicate environment in which those decisions are taken, the Court not only reaffirmed the principle of effective legal protection in its judgement in $2008,{ }^{11}$ but also insisted in $2013^{12}$ on the respect of the classical standard of proof requirements, since Kadi had been able to challenge in a substantiated manner the allegations made against him. In $Z Z$ this line of case law was applied to actions falling within the ambit of articles 27,28 and

\footnotetext{
10 Judgment of 15 May 1986, Johnston, 222/84, EU:C:1986:206; Judgment of 15 October 1987, Heylens et al., 222/86, EU:C:1987:442; Judgment of 8 December 2011, Chalkor v Commission, C-386/10 P, EU:C:2011:815; Judgment of 6 October 2015, Schrems, C-362/14, EU:C:2015:650; Judgment of 16 May 2017, Berlioz Investment Fund, C-682/15, EU:C:2017:373.

11 Judgment of 3 September 2008, Kadi and Al Barakaat International Foundation v Council and Commission, C-402/05 P and C-415/05 P, EU:C:2008:461.

12 Judgment of 18 July 2013, Commission and Others $v$ Kadi, C-584/10 P, C-593/10 P and C-595/10 P, EU:C:2013:518.
} 
31 of directive 2004/38, taken against Union citizens on grounds of public security. ${ }^{13}$

But, more generally speaking, in times of terrorism it has not been an easy task for the Court in matters involving national security interests or what is broadly defined as such to insist in quite a number of cases on the respect of the requirements resulting from the principle of proportionality and the rule of law in precisely those matters. ${ }^{14}$ If certain observers have advocated restraint in applying those principles - which is perhaps understandable from a political perspective - it should be borne in mind that EU law has never abided by a doctrine of political questions. On the contrary, the security exceptions with which the Court was confronted in its recent case law $^{15}$ have visibly been narrowly defined by the Union legislator, quite contrary to national regulations, which were pushing security prerogatives to their limits. Faced with that alternative, it might be understandable why the Court found that it was the orientation of national law rather than of Union law which was in need of correction.

3.

But speaking more precisely about the Member States' respect of the rule of law, the Court has in recent years repeatedly been called upon to judge actions brought by the Commission against the inobservance of certain ruleof-law guarantees, in particular of the independence of the judiciary and of the independence of specific administrative authorities ensured by Union

13 Judgment of 4 June 2013, ZZ, C-300/11, EU:C:2013:363.

14 See, for instance, judgments of 28 November 2013, Council v Fulmen and Mahmoudian, C-280/12 P, EU:C:2013:775; of 8 April 2014, Digital Rights Ireland and Others, C-293/12 and C-594/12, EU:C:2014:238; of 6 October 2015, Schrems, C-362/14, EU:C:2015:650; of 21 December 2016, Tele2 Sverige and Watson and Others, C-203/15 and C-698/15, EU:C:2016:970; of 26 July 2017, Council v LTTE, C-599/14 P, EU:C:2017:583; Opinion 1/15 (EU-Canada PNR Agreement) of 26 July 2017, EU:C:2017:592.

15 As regards articles 1 (3) and 15 (1) of directive 2002/58, see the judgment of 21 December 2016, Tele2 Sverige and Watson and Others, C-203/15 and C-698/15, EU:C:2016:970, paragraphs 69 et seq. 
law. ${ }^{16}$ But only some of those actions have been "counted" in the rule-of-law context, since the precise contours of the independence of regulatory bodies have always been subject to vivid debates. Indeed, this subject should be addressed with great caution. On the one hand, it is a constant feature of European integration that Member States do, at first, subscribe to a significant number of obligations which are even fairly clear-cut, but then - for divers reasons - do not manage to properly implement the corresponding acts of EU law, sometimes even not at all. Even years after the incorporation of the current article 260 in the Maastricht Treaty and its re-enforcement by the Lisbon Treaty, the sad history of the need for consecutive infringement procedures still cannot be considered as an infant disease of Union law.

It should therefore be born in mind that all Member States and Union institutions are on an equal footing before the requirements of the rule of law. Of course, there is a fundamental difference between an outright refusal to accept Union law or the jurisdiction of the Court and an infringement of Union law which is bona fide contested on legal grounds. Due to the evolutionary nature of Union law, the latter category may still comprise violations which appear, post factum, to be quite manifest. In the Court's daily practice, this line of demarcation might even appear less tangible than what my words seem to suggest. Nonetheless, it goes without saying that there is a fundamental difference in quality between those kinds of disrespect of the rule of law, even if the precise point of distinction may not easily be identified in the abstract. Given the historic dimension of the acceptance of the rule of law between European Member States and the unforeseeable consequences of its disrespect, of which the words of Walter Hallstein have reminded us, all our caution should be accompanied by a

16 Judgment of 6 November 2012, Commission v Hungary, C-286/12, EU:C:2012:687; Judgment of 8 April 2014, Commission v Hungary, C-288/12, EU:C:2014:237; Judgment of 9 March 2010, Commission v Germany, C-518/07, EU:C:2010:125; Judgment of 2 June 2016, Commission v Portugal, C-205/14, EU:C:2016:393; case Commission v Poland, C-530/16, pending; also see the judgment of 12 May 2011, Luxembourg v Parliament and Council, C-176/09, EU:C:2011:290. 
vivid awareness of what is at stake. It is this state of mind in which the Court has to look into cases which have quite recently been brought to its attention.

Last year a prominent case in which the Court was confronted with this twofold difficulty of having to be cautious was the action which the European Commission brought regarding the primeval forest in the Bialowieza region. This was an action against the Republic of Poland for the infringement of EU rules on environmental protection. While the main proceedings are still pending, the Court issued, upon a request of the European Commission, a first interim injunction on $27^{\text {th }}$ of July. In the further course of the proceedings the Commission, claiming that Poland had not respected the first interim injunction, asked the Court to order the Republic of Poland to pay a periodic penalty payment in case further interim measures which it was applying for would not be respected.

The Court, sitting in Grand Chamber, after an oral hearing considered the question carefully and gave a judgement on these interim measures on $20^{\text {th }}$ of November, only a few days before hearing the case on the merits. Relying primarily on the broad wording of article 279 , which confers on the Court the power to "prescribe any necessary interim measures", and on the purpose of this power,${ }^{17}$ the Court held that even if the powers resulting from article 279 were limited by its ancillary character it could indeed include the imposition of a periodic penalty payment, if such a measure were deemed necessary in the circumstances of a given case to ensure the full effectiveness of the interim measures ordered. ${ }^{18}$ In particular, the Court considered an effective application of Union law to be an essential component of the rule of law, a value enshrined in Article 2 TEU, and on which the European Union is founded. In the circumstances of the primeval

17 Order of 20 November 2017, Commission v Poland, C-441/17 R, EU:C:2017:877, paragraph 97 et seq.

18 Order of 20 November 2017, Commission v Poland, C-441/17 R, EU:C:2017:877, paragraph 104 et seq. 
forest of Bialowieza, the Court announced that a periodic penalty payment of at least 100000 Euros per day would be imposed in case of noncompliance with the Court's order. Subsequently, the Court has not been informed of any incident of non-compliance.

4.

As the Court has consistently held, the judicial dialogue between the Court of Justice and the courts of the Member States is a keystone of the judicial system as it is conceived by the Treaties. In collaboration with the Court of Justice the national courts and tribunals fulfil a duty entrusted to them both of ensuring that the law is observed in the interpretation and application of the Treaties. ${ }^{19}$ It is for this very reason that the judicial control exercised by national courts is of particular importance to ensuring the rule of law in the Union as a whole. If this might seem to be a rather self-evident insight for a European law scholar, it took the Treaty of Lisbon to include article 19, first paragraph, second subparagraph, in the Treaty of the European Union, which expressly states that Member states shall provide remedies sufficient to ensure effective legal protection in the fields covered by Union law. And it took until last Tuesday for the Court to give a first substantive interpretation of this provision in the so-called Portuguese judges case ${ }^{20}$.

While the decision taken in this case is, as such, rather unspectacular, the reasoning of the Court contains, beyond a strong affirmation of what the rule of law requires in terms of judicial protection, a new element which is of crucial importance to ensuring the respect of the rule of law by Member States in practice. In the first place, it is worth noting that the Court, being asked to give an interpretation of article 19, paragraph 1, second subparagraph, starts out by relating this provision to the common values of the Union laid down in article 2 TEU, which include the rule of law and, in

19 Judgment of 3 October 2013, Inuit Tapiriit Kanatami and Others v Parliament and Council, C-583/11 P, EU:C:2013:625, paragraph 99.

20 Judgment of 27 February 2018, Associação Sindical dos Juízes Portugueses, EU:C:2017:395, C-64/16. 
particular, justice. In that perspective the Court did not miss out on stating that an effective judicial protection is inherent in the rule of law. ${ }^{21}$ Hence, article 19 contains a concrete expression of the rule of law, by which the guarantee of effective judicial protection is made binding upon the Member States, providing remedies according to article 19 TEU. In dealing with what constitutes a court or tribunal in terms of Union law, the Court placed heavy weight on the independence of any such entity, which is again inherent in the task of judging. In that respect, judicial independence requires that a court may not be subject to any hierarchical constraint or subordination of whatever nature. ${ }^{22}$ Judicial independence also includes the protection of judges against their removal from office and even a level of remuneration which is adequate to the importance of the functions exercised. Nonetheless, the Court concluded that the austerity measures at issue could not be considered as an infringement of the independence of the members of the Portuguese court of auditors.

Those considerations can and should, of course, be read as a profound attachment of the Court to the principle of judicial independence and as a hint at its readiness to look even into rather technical regulations on the national level to examine whether they might or might not contain elements which put judicial independence at risk. Still, taken as such, this reasoning would contain nothing ground-breaking, if there were not an element which the Court put up front: When defining the scope of article 19, paragraph 1, second subparagraph TEU, ratione materiae, for which the text of this provision refers to the "fields covered by Union law", the Court ruled that this provision is applicable independently of a situation in which Member States are implementing Union law in the meaning of article 51, paragraph

\footnotetext{
21 Judgment of 27 February 2018, Associação Sindical dos Juízes Portugueses, C-64/16, EU:C:2017:395, paragraph 36.

22 Judgment of 27 February 2018, Associação Sindical dos Juízes Portugueses, C-64/16, EU:C:2017:395, paragraph 44.
} 
1, of the Charter. ${ }^{23}$ Hence, the Court made it perfectly clear that the requirements of Union law in terms of judicial independence are not limited to a more or less precisely defined situation in which Union law is in concreto implemented, but stretches to all national jurisdictions which might in general be confronted with questions relating to the application of Union law. ${ }^{24}$

This interpretation seems noteworthy, since it has implications which go far beyond the rather specific circumstances of the case at hand. According to that interpretation, any disrespect of the guarantee of judicial independence will have to be considered an infringement of article 19, paragraph 1, second subparagraph, TEU, if the judicial body in question is likely to be confronted with questions of Union law. There is no further necessity to examine whether this body is, in the case at hand, confronted with a situation in which Union law is implemented. In giving this answer the Court somehow indirectly echoes the debate on the limited effectiveness of the procedure foreseen in article 7 TEU, which makes it possible to suspend certain rights of a Member State in the case of a serious and persistent breach of the Union's founding values: The Court points the Commission to article 19, paragraph 1, second subparagraph, TEU and, at the same time, remains faithful to the orientation adopted earlier to resist the temptation to go beyond the limits of the scope of the Charter as set out in the first paragraph of its Article 51.

III.

In sum, it should be emphasized that throughout the various fields of law the case-law of the Court of Justice aims in general to ensure that a high level of protection is respected, be it in the field of consumer protection, as

\footnotetext{
23 Judgment of 27 February 2018, Associação Sindical dos Juízes Portugueses, C-64/16, EU:C:2017:395, paragraph 29.

24 Judgment of 27 February 2018, Associação Sindical dos Juízes Portugueses, C-64/16, EU:C:2017:395, paragraph 39.
} 
confirmed a while ago with regard to mortgage loans in Spain, ${ }^{25}$ in the area of non-discrimination on grounds of nationality, ${ }^{26}$, gender ${ }^{27}$ or age,${ }^{28}$ or as regards the scope of Union citizenship. ${ }^{29}$ While remaining committed to this general orientation the Court has, for example, not put into question national pension schemes based on a predetermined age limit. ${ }^{30}$ More recently it has considered that the right to free movement of Union citizens, as it is embodied in directive 2004/38, provides in principle for sufficient protection of third-country nationals who are members of the family of a Union citizen ${ }^{31}$ and, above all, that the restrictions imposed on that right by that directive are justified in order to prevent that Union citizens who are nationals of other Member States become an unreasonable burden for the social security system of the host Member State. ${ }^{32}$

As regards in particular the level of protection guaranteed by the Charter of Fundamental Rights, the recent case-law of the Court of Justice has left little doubt that the era of "Solange"-type claims has been overcome with the entry into force of the Charter. The latter has, indeed, rendered obsolete in practice the need for any reserve in favour of national, constitutional or supreme courts because of an insufficient level of protection of Union citizens. Even in the area of mutual recognition, recent case law concerning the risk of inhuman and degrading treatment following the surrender of a person under the European arrest warrant ${ }^{33}$ and following the transfer of a

25 Judgment of 21 December 2016, Gutiérrez Naranjo and Others, C-154/15, C-307/15 and C-308/15, EU:C:2016:980.

26 Judgment of 13 April 2010, Bressol and Others, C-73/08, EU:C:2010:181.

27 Judgment of 1 March 2011, Association belge des Consommateurs Test-Achats and Others, C-236/09, EU:C:2011:100. Judgments of 19 April 2016, DI, C-441/14, EU:C:2016:278 and of 11 November 2014, Schmitzer, C-530/13, EU:C:2014:2359.

29 Judgment of 18 December 2014, McCarthy and Others, C-202/13, EU:C:2014:2450.

30 Judgments of 11 November 2014, Schmitzer, C-530/13, EU:C:2014:2359, and of 19 April 2016, DI, C-441/14, EU:C:2016:278.

31 Judgment of 8 November 2012, lida, C-40/11, EU:C:2012:691.

32 Judgments of 11 November 2014, Dano, C-333/13, EU:C:2014:2358, and of 15 September 2015, Alimanovic, C-67/14, EU:C:2015:597.

33 Judgment of 5 April 2016, Aranyosi and Căldăraru, C-404/15 and C-659/15 PPU, EU:C:2016:198. 
seriously ill asylum seeker under the Dublin system ${ }^{34}$ should be able to withstand the criticism to which the Court was previously exposed.

As to recent comments pointing in the opposite direction, according to which the Court is too committed to the protection of fundamental rights, it should be stressed that of course the protection of fundamental rights cannot be an end in itself, justifying its maximal extension. It is also true that sensitivities and priorities can easily vary from one audience to another. However, the relevant case law seems far from being excessive. Indeed, in its judgment Association de médiation sociale of 15 January 2014 the Court has already held that Article 27 of the Charter cannot be invoked in a dispute between individuals in order to disapply a national provision which is incompatible with EU law. ${ }^{35}$ By means of this judgment the Court was able to allay the fears that all of the guarantees provided for in Title IV of the Charter could have a horizontal effect. In a similar vein, the Court held in M.A.S. and M.B. ${ }^{36}$ that the obligation to disapply national limitation periods liable to prevent the prosecution of VAT frauds and thus to affect the Union's financial interests does not extend to cases in which the disapplication entails a breach of the fundamental principle that offences and penalties must be defined by law. To arrive at this conclusion, the Court took into account that the limitation rules applicable to criminal proceedings relating to VAT had not been harmonised by the EU legislature and that the national authorities and courts remained free to apply national standards of protection of fundamental rights, provided that the level of protection offered by the Charter and the primacy, unity and effectiveness of EU law were not compromised.

In conclusion, the case law of the Court of Justice reflects quite strikingly that the famous formula characterizing the European Union as a community

\footnotetext{
34 Judgment of 16 February 2017, C. K. and Others, C-578/16 PPU, EU:C:2017:127.

35 Judgment of 15 January 2014, Association de médiation sociale, C-176/12, EU:C:2014:2.

36 Judgment of 5 December 2017, M.A.S. and M.B., C-42/17, EU:C:2017:936.
} 
based on the rule of law and the repeated recognition of the common values of the Union are much more than abstract references without any practical importance. The Court of Justice has with sincerity brought to life the values on which the Union rests, applying them on a case-by-case basis to the disputes brought to its attention. All in all, this case law has implemented our European values on a day-to-day basis and brought about real added value for the citizens of the Union, which is why it should not fear criticism. And still we need to make these values more visible and to strengthen our efforts in order to convince those who doubt that it is still worthwhile to continue on the long road to European integration. 